九州大学学術情報リポジトリ

Kyushu University Institutional Repository

\title{
On The Chemical Nature of Vitamin D
}

Takamiya, Etsuo

Biochemical Laboratory, Department of Agriculture, Kyushu Imperial University

https://doi.org/10.5109/22558

出版情報: 九州大学大学院農学研究院紀要. 3 (1)，pp.1-27，1930-12. Kyushu Imperial University バージョン：

権利関係 : 
Journal if the lepartment of Agriculture, Kyushu Injerial Lniversity, Vol. 3, No. I.

Decemlier 25, 1930.

\title{
ON THE CHEMICAL, NATURE OF VITAMIN D
}

\author{
Etsuo Taknmiva
}

Huldschinsky (1919) confirmed that ultra-violet rays exert a curative action on rickets when the rickety rats are directly irradiated. McCollum and co-workers (1922) reported that cod liver oil contains in abundance some calcium-depositing substance which is present in butter fat in but very slight amounts and which exerts a directive influence on bone development. This substance' is apparently distinct from fat-soluble vitamin A. STEENBOCK and BLACK (1924) demonstrated that rickets-producing dicts after irradiation with a mercury vapour quartz lamp exert a curative action on rickets, being activated antirachitically. STEenвock and co.workers (I925) reported that puritied proteins, carbohydrates, fats, salts, water, ether, hydrochinon, pliloroglucin, or paraffin hydrocarbons could not be activated, but cholesterol purified by crystallization, then as benzoate, and finally as acetate, as well as pliytosterols, could be photochemically activated after irradiation with a mercury vapour quartz lamp. Many investigators, thereafter, studied in detail on the activated cholesterol after irradiation, and for some time until the appearance of ROSENHEIM and WLBSTER's paper, it was generally held that cholesterol is the precursor of vitamin $D$. Wintuaus and Hess (1926) confirmed the fact that if cholesterol was purified by the formation of derivatives (e. g., dibromide), it could no longer be activated by ultra-violet rays, and then concluded that the mother substance of vitanin $D$ is an impurity and not cholesterol, and sugrgested that ergosterol is probably the mother substance of vitamin D, since it cannot be separated from chulesterol by physical methods, and yet it is active in preventing rickets in mere traces after irradiation. Rostenem and Wenstein (I927) purified cholesterol as far as possible

1 This is now called vitamin $\mathrm{D}$. 
by repeated crystallization, then converted it into the dibromicle and regenerated the cholesterol by reduction. This purified cholesterol could not be activated after irradiation, which showed that it is not cholesterol, which is the precursor of vitamin $\mathrm{D}$, but some impurity which is destroyed by bromination. They announced that ergosterol is the parent substance of vitamin D. Rosknhim and WEBSTER (I928) presented evidence that in ergosterol not only a typical ring structure but also the specific position of the three unsaturated bonds is essential for photochenical conversion into vitamin $\mathrm{D}$.

Stuclies on vitanin D, therefore, have bcen advanced from the relation "pro-vitamin + ultra-violet rays $\rightarrow$ vitamin $\mathrm{D}$ " to the relation of "ergosterol + ultra-violet rays $\rightarrow$ vitamin D". Nevertheless, the significance of the action of ultra-violet rays on the photochemical conversion of ergosterol into vitamin $\mathrm{D}$ still remains unexplained. If this problem could be solved, the chemical nature of vitamin $\mathrm{D}$ would be elucidated. I present evidence in this paper from my experimental results that the action of ultra-violet rays in all respects, especially concerning problems on the formation of vitamin I) is closely analogous to that of ozone, and then suggest that vitamin 1) is imperfectly ozonized ergosterol.

My best thanks is due to Prof. Dr. Y. Okuda and Prof. Dr. M. Yukawa for their kind guidance.

\section{ENZYMIC HYDROLYSIS-VIELOCITY OF VEGETABLE OIL BEFORE AND AFTER IRRADIATION WITII UIIRA-VIOLET RAYS}

Six vegetable oils, differing in iodine value-coconut oil, olive oil, almond oil, cottonseed oil, soy-bean oil, linseed oil-were employed.

The castor-bean lipase preparation applied for this experiment was obtained as fine white powder, from castor-beans after removing their husks by hand, extracting the kernels with petroleum-ether.

The method of estimating for hydrolysis-velocity of oil by the lipase was similar to that of R. WILISTÄTLER (1924) except that a cylindrical botle with a glass-stopper, a definite diameter and a flat bottom was used, for the reason stated in my paper (1926). The lipase preparation $(0.2 \mathrm{~g})$ was weighed into the estimating bottle (diameter $3.6 \mathrm{~cm}$.), then 2.8 c.c. $^{2}$ of each vegetable oil added as substrate, and shaken for one

2 The same vilume of each substrate must he used in the mutual comparison for cnsymic hydrolysis-velucity for the reason slatcd in my paper (1926). 
minutc, then 2 c.c. of acetic-acetate buffer solution $(P I I=4.7)$ added and shaken well for 3 minutes, then placed standing in a constant water-bath $\left(30^{\circ} \mathrm{C}\right)$ for 3 hours. The reaction mixture was washed cautiously into a flask with $30 \mathrm{ccc}$ of 95 per cent ethyl-alcohol and 15 c.c. of ether, and titrated with C.I $\mathrm{N}$ potasium hydroxide solution, using phenolphthalein as indicator. The enzymic hydrolysis percentage of each oil was calculated from the quantity of liberated fatty acids to each ester value.

A. roc.c. of each vegretable oil taken in a crystallization dish (diameter $9.5 \mathrm{~cm}$.) were clirectly irradiated for 3 hours at a distance of about $19 \mathrm{~cm}$. from a mercury vapour quartz lamp in a water-jacketed box, the temperature duing imaliation rising up to about $60^{\circ} \mathrm{C}$. The enzymic lydrolysis-velocity of each original regetable oil and of its irradiated form was as follows:

Table I

\begin{tabular}{|c|c|c|c|}
\hline \multirow{2}{*}{ Siulsstrate } & \multicolumn{2}{|c|}{ Hydrolysis-velocity $(\%)$} & \multirow{2}{*}{$\begin{array}{l}\text { 1)ecreasing ratio } \\
(1 / \mathrm{a} \times 100)\end{array}$} \\
\hline & orisinal (a) & irradiated (b) & \\
\hline Cocomt nil & $5 ? 1$ & 36.6 & 700 \\
\hline alive sil & 44.3 & 27.0 & 60.9 \\
\hline Almond oil & 410 & 23.7 & 57.8 \\
\hline Coltwnseed vil & 40.7 & 20.0 & 49.1 \\
\hline Siny-bean vil & $4 \mathrm{I} \cdot 5$ & 19.5 & 46.9 \\
\hline J.inseed oil & 35.4 & I6.I & $45 \cdot 5$ \\
\hline
\end{tabular}

B. Cottonseed oil (ro c.c) taken in a crystallization dish (diameter $9.5 \mathrm{~cm}$.) was directly irradiated for a definite time at a distance of about $18 \mathrm{~cm}$. from the lamp in a water-jacketed box, the temperature during irradiation rising up to about $45^{\circ} \mathrm{C}$. The enzymic hydrolysisvelocity of the original oil and of its irradiated form for a definite time was as shown in table 2 .

From these experimental results, it became evident that after irradiation with ultra-violet rays, the irradiated vegetable oil was less readily hydrolysed by the enzyme than was the original, and the greater the iodine value the greater is the influence of irradiation, and that the 
decrease in enzymic hydrolysis-velocity of oil is directly proportional to the length of time of irradiation.

Table 2

\begin{tabular}{c|c}
\hline Tine for irradiation (hr.) & Ifydrolysis velocity $(\%)$ \\
0.0 & 40.7 \\
0.5 & 32.3 \\
1.0 & 24.3 \\
2.0 & 22.3 \\
21.0 & 0.0 \\
\hline
\end{tabular}

II. ACTION OF ULTRA-VIOLFT RAVS UPON VEGETABLE OIL SEEN IFROM THE VIEWPOINT OF ENZYMOLOGY

The action of ultra-violet nays upon vegetable oil was investigated, the change in enzymic hydrolysis-velocity of oil caused by irradiation being the criterion.

A. ACID VALLE, SAPONIFICATION VALUE AND ESTER VALLE OF VEGETABLE OIL ANI) OF ITS IRRADIATED FORM

The irracliated vegretable oil was prepared similarly to that of the experiment I. A.

Table 3

\begin{tabular}{|c|c|c|c|c|c|c|}
\hline \multirow{2}{*}{ Sample } & \multicolumn{2}{|c|}{ Acid value* } & \multicolumn{2}{|c|}{ Saponification value } & \multicolumn{2}{|c|}{ Ester value } \\
\hline & Y & II & I & JI & I & II \\
\hline Cocunut oil & 2.0 & 2.6 & 242.9 & 243.7 & 240.9 & $24 \mathrm{I} \cdot \mathrm{I}$ \\
\hline (live oil & $4 \cdot 5$ & $5 \cdot 5$ & 193.5 & 194.8 & $189 . \mathrm{C}$ & 189.3 \\
\hline Aluond oil & $1 \cdot 3$ & 2.8 & 194.7 & 1956 & 193.4 & 192.8 \\
\hline Cutlonsecd oil & 0.2 & 2.0 & 195.9 & 199.1 & $195 \cdot 7$ & $x 97.1$ \\
\hline Siony bean oil & 0.8 & 2.2 & 193.0 & I 94.4 & 192.2 & 192.2 \\
\hline Linseed oil & 2.5 & 4.8 & $\mathrm{r} 94.2$ & 197.4 & 191.7 & 192.6 \\
\hline
\end{tabular}

\section{I : Original oils}

II. Irradiated oils

* This acid valuc was estimated after the oil in alout 5 times distilled water was cautiously warmed on a witer bath for 3 hours. 
After irradiation with ultra-violet rays, acid value and saponification value of each oil increased noderately, but its ester value remaincel unchangred. The increase in saponification value, therefore, is evidently due to the increase in acid value.

B. IOMINE VALUE OF VEGETABLE OIL AND

ITS ENZYMIC HYDROLYSIS-VELOCITY

Table 4

\begin{tabular}{|c|c|c|}
\hline Substrate & $\begin{array}{l}\text { Iodine value } \\
\text { (Wijs' method) }\end{array}$ & $\begin{array}{c}\text { 1 Iydrolysis-yclocity } \\
(\%)\end{array}$ \\
\hline Cocomut oil & $7 \cdot 3$ & $5=.1$ \\
\hline Olive oil & $: 4 \cdot 3$ & $44 \cdot 3$ \\
\hline Almonrl oil & 96.3 & 41.0 \\
\hline Coltonsecd oil & 109.4 & 40.7 \\
\hline Soy-bean oil & 133.8 & 41.5 \\
\hline Linseed nil & 183.4 & $35 \cdot 4$ \\
\hline
\end{tabular}

These cxperimental results indicate that there cxists a certain correlation between the iodine value of oil and its enzymic hydrolysisvelocity; namely, the greater the iodine value the less is the velucity. From this fact, the nutritive value of fat and oil which was already made evident to be directly proportional to its enzymic luydrolysis velocity by Y. Matscyama and M. Yosmima (I927), can be assumed to be inversely proportional to its iodine value. This assumption will also be confirmed by the results of feeding experiments which were carried out by other investigators such as J. Ozaki (1927) and S. Ueno (1927).

\section{IODNE VALUE OF IRKADATTES OIL AND \\ ITS EXZYMIC IIYIROI,YSIS-VELOCITY}

The irracliated vegetable oil was prepared similarly to that in the experiment I. A.

From the experinental results given in table 5 , it became eviclent that after irradiation with ultra-violet rays, the vegetable oil is less readily hydrolysed by the cnzyme than is the original, and the greater the iodine value the greater is the influence of irradiation, and that the 
iodine value of irradiated oil became less than that of the original, and the greater the iodine value the greater is the influence of irradiation. These relations are readily seen in table 6 , in which the figurcs given in table 4 and 5 are combined, and the recreasing ratios are compared.

Table 5

\begin{tabular}{l|c|c}
\hline $\begin{array}{c}\text { Sul,strate } \\
\text { (irradiated oil) }\end{array}$ & $\begin{array}{c}\text { Iodine value } \\
\text { (Wijs' method) }\end{array}$ & $\begin{array}{c}\text { Irydrolysis-velocity } \\
(\%)\end{array}$ \\
\hline Coconut oil & 7.0 & 36.6 \\
Olive oil & 80.5 & 27.0 \\
Almund oil & 90.7 & 23.7 \\
Cotlonseed oil & 39.5 & 20.0 \\
Soy bean oil & 121.8 & 19.5 \\
l.insecd .il & 163.8 & $\mathbf{1 6 . 1}$ \\
\hline
\end{tabular}

Table 6

\begin{tabular}{|c|c|c|c|c|c|c|}
\hline \multirow{2}{*}{ Sulutrate } & \multicolumn{2}{|c|}{$\begin{array}{l}\text { Hydrolysis- } \\
\text { velucity }(\% \text { ) }\end{array}$} & \multirow{2}{*}{$\begin{array}{l}\text { 1)ecreasing } \\
\text { matio } \\
(1, / a \times 100)\end{array}$} & \multicolumn{2}{|c|}{ Totine value } & \multirow{2}{*}{$\begin{array}{l}\text { Decreasing } \\
\text { ratio } \\
(1, a \times 100)\end{array}$} \\
\hline & $\mathrm{I}(\mathrm{a})$ & II (b) & & $I(a)$ & II (b) & \\
\hline Giconat oil & $5^{2.1}$ & 36.6 & 70.2 & $7 \cdot 3$ & 7.0 & 95.9 \\
\hline Alive oil & $44 \cdot 3$ & 27.0 & 60.9 & $8 \cdot 1-3$ & 80.5 & 95.5 \\
\hline Amond oil & 41.0 & $23 \cdot 7$ & 57.8 & 96.3 & 90.7 & 94.2 \\
\hline Contunsiecel oil & 40.7 & 20.0 & 49.1 & $10.9 \cdot 4$ & 99.5 & 90.9 \\
\hline Soy lean oil & $41 \cdot 5$ & $19 \cdot 5$ & 46.9 & $1,3.8$ & 121.8 & 91.0 \\
\hline 1.inseed ail & $.35 \cdot 4$ & 16.1 & $.45 \cdot 5$ & 183.4 & 163. & 89.3 \\
\hline
\end{tabular}

These experimental results indicate that the decreasc in iodine value of irradiated oil is in an intimate relation to that in cnymic hydrolysisvelocitly. But on the other hand, it was already made evident in the expcriment II. B that the enzynic hydrolysis-velocity of non-irradiated oil is inversely proportional to the iodine value, and the greater the iodine value the less is the velocity. Therefore, in other modes except the simple saturation, the iodine value must be decreased. What is 
here neant by "other modes" was afterwards confirmed on investigation (see the experiment II. F and II. F) to be the formation of ozonicle.

And it is also evident from table 6 that the decreasing ratio in enzymic hydrolysis-velocity of oil is far greater than that in iodine value. We must conclude, therefore, that the decrease in enzymic hydrolysis-velocity of oil after irradiation is more probably due to the fact that the presence of oil altered by irradiation retards in some way the enzymic activity, ather than to the fact that such altered oils are no longer hydrolysed by the enzyme. (Of course, what is here meant by altered oil corresponds to the ozonized oil as scen from the brief note above.)

\section{VISCOSITY OF IRRADUATED OIL ANI ITS ENZYMIC}

\section{HYIOROLYSIS-VELOCITY}

Vegetable oil became strongly viscous after irradiation with ultraviulet rays for a long period. This made it essential to study the corrclation between the viscosity of oil and its enzymic hydrolysis-velocity. For this purpose, Osrwald's viscositometer was employed, the temperature being $30^{\circ} \mathrm{C}$, sample oil measuring 5 c.c., and tine (seconds) spent in dropping off of oil measured, and the viscosity of oil was calculated according to the following formula.

$$
\eta=\mathrm{dt}
$$

$$
y \text { : viscosity d: sp. gr. } t \text { : time (second) }
$$

\begin{tabular}{|c|c|c|}
\hline Sample & Viscusily $(n)$ & Hydrolysis-velocily $(\%)$ \\
\hline Olive oil & 369.8 & $44 \cdot 3$ \\
\hline Almond oil & $33=8$ & 41.0 \\
\hline Cottonseed oil & 300.7 & 40.7 \\
\hline Soy-bean oil & 266.7 & $4 \div 5$ \\
\hline Linseed vil & 228.4 & 35.4 \\
\hline
\end{tabular}

Table 7

It became evident from the experimental results that the viscosity of oil runs parallel with its enzymic hydrolysis-velocity; namely, the greater the viscosity the greater is the velocity. 
Table 8

\begin{tabular}{c|c}
\hline Time for irradiation (min) & Viscosity $(r)$ \\
\hline 0 & 300.7 \\
30 & 315.6 \\
60 & 342.5 \\
180 & 490.4 \\
\hline
\end{tabular}

Cottonseed oil was used and irradiated similarly to that in the experiment I. A.

From the experinental results obtained above, it became evident that the greater the viscosity the greater is the velocity, and that the viscosity of oil increases gradually according to the elongation of time of irradiation. If seen from the point of vicw of viscosity, it would appear the enzynic hydrolysis-velocity of oil should be increased through irradiation with ultra-violet rays, but, in point of fact, the enzymic hydrolysis-velocity of oil was strongly decreased after irradiation (see the experiment I. A and I. B ). Therefore, the incrcase in viscosity of irradiated oil is seen to be independent of the decrease in its enzymic hydrolysis-velocity.

E. ACTION OF OZONE UHON OIL

The Sizmaxs ozone-generator with ten-tubes was employed as an ozonc-generator and ozone was generated by passing oxygen gas in at $4 \mathrm{l} / \mathrm{h}$ velocity, voltage being raised first from $\mathrm{I}$ ro volts to 8,000 volts and after 5 minutes 10,000 volts. Under this condition, 20 c.c. of cottonseed oil were ozonized for 30 minutes.

\section{Table 9}

\begin{tabular}{l|c|c|c} 
Coltonsecd oil & $\begin{array}{c}\text { Ifydrolysis- } \\
\text { velocily }(\%)\end{array}$ & Jodine value & Viscosity $\left(r_{1}\right)$ \\
\hline Original oil & 40.5 & ro.1 & 300.7 \\
Ozonized oil & 24.7 & 98.0 & 408.1 \\
\hline
\end{tabular}


As these cxperimental results indicate, when compared with the original oil, the ozonized form decreased strongly in its en\%ymic hydrolysis-velocity, decreased in its iodine value and increased in its viscosity. This phenomena caused by the action of ozone are readily seen to be quite in line with those caused by irradiation with ultra-violet rays.

Thus, the action of ultra-violet rays upon vegetable oil is readily seen to be merely the action of ozone which is generated during irradiation. From this the facts now became evident that the acid value of oil increases after irradiation, and also (as described in the expcriment II. C.) that the presence of ozonized oil retards the enzymic activity in some way.

\section{F. REAL ACIION OH ULTRA-VIOLET RAYS LPON OIL}

The action of ultra-violet rays upon vegetable oil can be regarded as ef uivalent to the action of ozonc. (sce the experiment II. E.) Whether ultra-violet rays in themselves exert the action upon oil which has been generally considered as the action of ultra-violet rays or uitra-violet rays in themselves produce no such result but play a rôle for the greneration of ozone the results of which were gencrally supposed to be the action of ultra-violet rays formed a further problem which was investigated by means of the following cxperimental method.

Two crystallization dishes of the same diameter $(38 \mathrm{~cm})$ and content ( $\mathrm{I} .4$ c.c.) were filled to the brim with cottonseed oil. On one of these a quartz plate was cautiously slid in such a way as not to form bubbles, and the other dish was covered over at a distance of $2 \mathrm{~cm}$. with a millboard which had been inlaid with the same quart\% plate. These two portions of cottonsced oil in the two dishes were irradiated under the same conditions in a water-jacketcd box at a distance of about $18 \mathrm{~cm}$. from a mercury vapour quartz lamp, the temperature during irradiation rising up to about $50^{\circ} \mathrm{C}$. In the former casc, the oil was irradiated with ultra-violet rays but without the action of ozone produced luring irradiation (designated as "a" in table ro) and in the latter casc, the oil was affected by both the irradiation of ultraviolet rays and the action of ozone produced during irradiation (designated ats "b" in table 10).

The experimental results indicated that in the former case (a), there was no change in its enzymic hydrolysis-velocity within the cxpcrimental error but in the latter case (b), it apparently decreased. 
Therefore, it became cvident that ultra-violet rays in themseives have no such affects as were hitherto attributcal to the action of ultra-violet rays but plays a rôle of generating an ozone, which action was in practice recognized as the action of ultra-violet rays.

Table ro

\begin{tabular}{|c|c|c|}
\hline Cottonsecd oil & 'Tine for irractiation (hr.) & Ilydrolysis velocity $(0,0)$ \\
\hline ()riginal oil & 0.0 & 41.0 \\
\hline il & $1 \cdot 5$ & 40.8 \\
\hline vil & 5.0 & 40.4 \\
\hline oil & $\mathbf{I} .5$ & 39.3 \\
\hline (ii) & 5.0 & 36.6 \\
\hline
\end{tabular}

It may be summarized from experiment II. that the action of utrariolct rays upon regatable oil sien from the ricapoint of enaynology is notling but the action of ozone, and the ultra-violet rays correspond to an osone-generetor.

\section{COMPARISON BETWEIEN THE ACTION OF OZONE AND THAT OF ULTRA-VIOLET RAYS UPON CIIOLESTEIROI AND OII.}

The fact was made evident from the cxperiment II. that the action of ultra-violet rays scen from the viewpoint of enzymology upon vegetable oil is no more than the action of ozone, and the ultra-violet rays correspond to an ozone-generator. Consequently the effects of ozone and ultra-violet rays upon cholesterol and oil were compared in this experiment by means of the criteria of photoactivity, colour reactions, etc.

\section{A. PHoroderivery}

K. TAKLHAsul and S. Hamano first discovered the fact that iitamin A preparation is photoactive, and $S$. Humso (1925) reported that cholesterol and oil became photoactive after irradiation with ultra-violet rays. This problem was, thereafter, deeply investigated by. II. Volimes 
(1926), J. Stritesky (1927) and N. S. Lucas (1926). And it becane evident that photodctivity is not due to any secondary radiation given out by the photoactive substance but seems to be due to the emanation of some substance from the photoactive substance. Above all, photoactivity is being observed with interest in relation to vitamins.

Photoactivity was determined as follows. A crystallization dish possessing a diameter $(3 \mathrm{~cm}$.) and a height $(1.6 \mathrm{~cm}$.) which was scrved with I gr. of sample was taken to a dark room and a photographic plate (Iion Ficlipse Ortho was used throughout these experiments) was laid sentitive side downwards on the sample. The whole was then placed in a light-tight box, wrapped in a photographer's black cloth, and kept in a dark room for 24 hours. The development of the plate was carried out as carefully as possible to be uniform throughout the experiment.

First, by repeating the experiment I confirmed the fact that after irradiation with ultra-violet rays, cholesterol and oil becone photoactive and their photoactivity become more intense, and oleic acid became strongly photonctive, but palmitic and stearic acid did not. From this fact, it became clear to be due to the unsaturated fatty acids of which the oil consists, that the oil becane photoactive after irradiation with ultra-violct rays.

Next, the photoactivity of cholesterol and oil after the action of ozone was invostigated. The SIEMENs' ozone-generator with ten-tuhes was employed as an ozone-generator, and ozone was generated by passing oxygen gas in at $41 / \mathrm{h}$ velocity, voltage being first raised from 110 volts to 8,000 volts and after 5 minutes to 10,000 volts. Under this condition, 4 c.c. of olive oil were ozonized for 1 hour, $1.5 \mathrm{gr}$. of cholestcrol for 40 minutes (this called "ozonized cholesterol I"), and white crystalline powder separated out by ozonizing cholesterol (2 gr.) dissolved in 160 c.c. of hexane was dried in vacuum over calcium chloride and paraffin (this called "uzonized cholesterol II")3. The photoactivity of these ozonized substances was as follows. Ozonizcl olive (iil (see Fig. I. B) was photoictive as well ats irradiated olive oil and ozonized cholesterol I (sce Iig. 2. C.) was strongly photoactive and also ozonized cholesterol II (sec lig. 2. 1)) violently. It became evident that cholesterol and oil become photoactive as well by the action of ozone as by that of ultra-violet rays.

3 See (. D). Harries; Untersuchngen ilser das (whe und seine linwirkurg auf organische Verlindung, s 374 . 


\section{B. COHOCR REACTIONS}

The fact has been generally admitted that cholesterol after irradiation gives different and specific colour reactions from that of the original one. In this experiment, some comparison of colour reaction between irradiated cholesterol and the ozonized one was carried out by means of the colour reactions of irradiated cholesterol proposed by many investigators.

SHEAR's colour reaction for vitamin D (1926).

The SHEar's reagent was prepared by adding I part of conc. $1 \mathrm{ICl}$ to about 15 parts of aniline which should be redistilled before using. Boiling a small quantity of purified cholesterol with the reagent in a test tubc for about half a minute gives a clear pale yellow solution, but when imadiated cholesterol is used, it gives a red colour which becomes intense on standing. IJe announced that this colour reaction is characteristic for vitamin I). Against this announcement Rosestery and Wrisster (1926) published an antagonistic opinion that the SHEAR's colour reaction is not specific for vitamin $\mathrm{D}$ and appears to be due to the formation of organic peroxides. In reply to this antagonistic opinion of Rosenhery and Wenster, Sifear and Kramer (1926) answered and declaring that the question as to how close a conncction exists between the chronogenic substance (or substances) and the antirachitic fuctor remains to be solved and the object was to obtain an antirachitically active fraction from irradiated cholesterol with aid of this colour rcaction; and they sepurated actually "U. V. oil of cholesterol" as an atirachitically active fraction. MOORE and WILLMOTT (I927) reported from their expcrimental data that the Snesk's colour reaction is not specific for vitamin D. Sexion (1928) studied the effects of the SHeir's reagent upon a number of sterol cierivatives and concluded that the SHEAR's colour reaction is by no means specific for vitamin 1) but on the other hand the positive reaction given by irradiated ergosterol and ketones is in harmony with the view expressed by IIEILbrox, MorTon and Sexrox (1928) that the antirachitic vitamin is possibly ketonic in character. Above all, it is evident fact that after irradiation with ultraviolet rays, cholesterol, ctc. for the first time give the Shear's colour reaction.

In my experiment ozonized cholesterol I and ozonized cholesterol II together positively gave the SHEAk's colour reaction.

Steigmaxn's colour reaction for vitamin D (1928). 
When 5 c.c. of fuchsin solution ( $1: 10,000$ ) decolorized with hydrosulfit $\left(\mathrm{Na}_{2} \mathrm{~S}_{2} \mathrm{O}_{4}\right)$ are added to an alcololic solution of sample, ordinary fuchsin colour appears again, and it is diluted with some amounts of distilled water, and then again decolorized by adding of a little cxcess of hydrosulfit. After standing for I-2 hours, a specific blue-violet colouration appears when sample containing vitamin $D$ are used. Steigmaxx announced that this fuchsin aldeliyde colour reaction is specific for vitamin D and concluded from his colour reaction cxperiment that vitamin $\mathrm{D}$ will probably be aldehyde or unsaturated ketone and that vitamin $\mathrm{D}$ will have a atomic group $>\mathrm{C}: \mathrm{C}: \mathrm{O}-$ in its molecule.

I investigated the question as to whether cholesterol gives the Steigmanx's colout reaction after the action of ozone or not. Cholesterols ozonized for 5,10 and 40 minutes, and ozonized cholesterol I respectively positively gave the STEIGMan's colour reaction and among them, that for 40 minutes was the strongest. When cholesterol (2 gr.) dissolved in 50 c.c. of carbon tetrachloride was ozonized for 2 hours and petroleum-ether added to it, white crystalline powder was precipitated which was dried in vacuum over calcium chloride and paraffin. This white crystalline powder also gave the STEIGMANN's colour reaction strongly.

Fulek, Myrbäck and Karlssox (1926).

reported that irradiated cholesterol gave different colour reactions from that of the original when compared by means of the four cholesterol colour reactions (e.g., A-reaction (Whitby's method), B-reaction (Whitby's method), C-reaction (Whitby's method), D-reaction (I larden's method); nanely, at least among the four colour reactions, first $\mathrm{C}$ - and A- reaction, and next B-reaction were eliminated.

I confirmed experimentally the fact that ozonized cholesterol II gave no $\mathrm{A}$ - and $\mathrm{C}$ - reactions at all and coloured a pale yellowish-pink colour emitting a green fluorescence in case of B-reaction, and gave no colouration on the addition of furfurol and conc. sulphuric acid, and coloured a yellowish-brown colour on the addition of anhydrous acetic acid; namely, ozonized cholesterol II did not give the $\mathrm{A}_{-}, \mathrm{B}_{-}, \mathrm{C}_{-}$, and D- cholesterol colour reaction.

\section{OTHER PROL'ER'IHES}

It has been generally recognized that the melting point of cholesterol depresses after irradiation with ultra-violet rays. For example, 
EUlek, MrRbäck and KARssion (1926) reported that when exposed to a mercury vapous quartz lamp at a distance of $4 \mathrm{~cm}$, the temperature Juring irradiation rising up to $150^{2} \mathrm{C}$, the cholesterol melted and became a porous, yellowish brown coloured glassy substance after cooling and the melting point of these substances first depressed and again rose according to the elongation of time of irradiation.

I confirmed the fact experimentally that the melting point of cholesteris depressed after the action of ozone; namely, the melting point of original cholesterol was $146^{\circ} \mathrm{C}$, that of ozonized cholesterol I $138^{\circ} \mathrm{C}$ and that of ozonized cholesterol II 1 I $3-12 \mathrm{I}^{\circ} \mathrm{C}$.

It has been also senerally rocognized that cholesterol becomes incapable of precipitation with cligitonin after imadiation with ultra-violet rays. I further confirmed experimentally the fact that cholesterol becane incapable of precipitation with digtonin after the action of orouic.

It nay be summarized from experiment III that the action of osone ufon cholesterol and oil as regards photactinity, colour reactions, etr., is closely analogons to that of ultra-riolet rays.

\section{BEHAVIOUR OF OZONE FOR THE FORMATION OF VITAMIN 1) AND FOR THE IILALING OF RICKETS}

It was shown in the preceding experiments that when seen from the viewpoint of enzymology, the action of ultra-violet rays upon vegetable oil is no more than the action of ozonc and the ultra-violet rays correspond to an ozone-generator, and also that the action of ozone is closely analogous to that of ulla-violet rays as regards photoactivity, colour reactions, etc.

If these several phenomena caused by the irradiation with ultraviolet rays in photoactivity, colour reactions, etc. could be shown to stand in some relation to the photochemical conversion of pro-vitamin into vitamin $\mathrm{D}$, it would be readily secn that crgosterol could be converted into vitanin $D$ after the action of ozone, without irradiation with ultraviolet rays. And if ergosterol would not become an antirachitically active substance after the action of ozone, it would be seen that the phenomena obtained above would stand in no relation to the photochenical conversion of ergosterol into vitamin $\mathrm{D}$, and it would be a psetudo-phenomena caused by the accessory action of ultra-violet rays.

Above all, it will be suggested in the extent of my experiments that a correlation such as exists between vitamin I) and ultra-violet 
rays will also exist between vitamin $D$ and ozone. In this experiment, consequently, I attempted the feeding experiments to ascertain whether ergosterol becomes an antiraclitically active substance after the action of ozone or not, and whether ozone exerts a curative action on rickets when the rickety rats fed in an ozonized atmosphere or not.

A. REIATION LETWELA THE PHOTOCHEMICAL FOKMATION OF VIMAMIN O AND UNHATION PRUCESSES

Many investigators have hitherto attempted to ascertain whether oxidation does or does not play a role in the activating process of irradiation with ultra-violet rays. This problem was here discussed in detail in the literature.

Schul\%, Zibglek and Morse (I927) suggested that it seems probable that the ultra-violet rays might cause a reaction to take place at the double bond, possibly an oxidation, and if irradiation does cause an oxidation of cholesterol, one rould not expect a very deep seater change, and the milder the oxidizing agent, the simpler is the resulting product and the more likely that such a compound could be obtained by the irradiation of cholesterol with ultra-violet rays. But $\alpha$ - and $\beta$ cholesteryl-oxide, hydrocholesterol, and $\alpha$-cholestantriol were hown to be the antirachitically inactive substances.

Hess and Windaus (1926) investigated the antirachitic potency on a number of cholesterol derivatives both when irradiated and when not, and anounced that cholesterol ozonide is antirachitically inactive in either case. But they did not describe how they prepared the cholesterol ozonide.

Hess and Werssrock (1925) irradiated a linseed oil in an atmosphere of nitrogen, in order to ascertain whether oxidation plays a role in the activating process or not. To this end a very small amount of linseed oil was placed in a quartz tube and the air removed from the oil by means of suction. Nitrogen was then run into the tube, after it had been passed through pyrogallol and over soda-lime. The quartz tube containing the oil was evacuated and flushed with nitrogen several times. The oil was then irradiated for $1 / 2$ hour at a distance of 6 inches. And they announced that the lack of oxysen did not prevented the activation and that as far as could be judged this oil prevented rickets as well as that which was irraliated in air. 
Rosenheim and Webstek (1926) evacuated the flask containing cholesterol which had been left evenly distributed as a thin film adhering firmly to the sides, and afterwards filled it with pure nitrogen and repeated this process several times, and then carried out the irradiation of the flask. And their experimental data showed apparently no difference for the photochemical formation of an antirachitic substance from the cholesterol whether irradiated in nitrogen or in air.

On the contrary, YoDen (1926) reported that there was no noticeable difference in the response to the test for peroxidation whether cholesterol in a quartz flask was irradiated in air or in nitrogen purified according to the precautions observed by Hess and WEINSTOCK (1925), and that examinations on a number of vegetable oils, cod liver oil and cholesterol for peroxidation showed (I) correlation between apparent antirachitic potency and peroxidation in untreated samples, (2) correlation between apparent potency and peroxidation in irradiated samples and (3) no correlation between apparent potency and peroxidation in excessively irradiated samples.

Vollmer and Serebrijski (1926) suggested from their experimental data on photoactivity that the antirachitic activation of inactive substances through ultra-violet radiation is regarded as oxidation, peroxidation or ozonization of easily oxidable organic compounds.

As readily seen from the above-described literature, the question whether oxidation plays a rôle in the activating process or nut, has not yet been decisively settled.

On the other hand, from the quantity of radiant energy necessary to form an amount of vitamin D sufficient to cause a demonstrable deposition of calcium in the bones of a rachitic rat, the weight of vitanin $\mathrm{D}$ synthesized is calculated to be $2 \times 10^{-8} \mathrm{gr}$. on cholesterol by Fosminimer, Daniels and Strangock (1928) (it should be noted that this is the whole dose during the ro days' test period, not a daily dose.) From the feeding experiments, Rosknnem and Webster (1927) confirmed the fact that irradiated ergosterol in daily dose of $\mathbf{I} \times 10^{-7} \mathrm{gr}$. cures and prevents rickets in rat on a rachitogenic dict and Cowaru (1928) showed that the daily dose of inadiated crgosterol necessary to give a positive result is $2 \times 10^{-8} \mathrm{gr}$.

From this literature, it is now evident that vitamin $D$ in very small quantity is capable of curing and preventing rickets in rats. If something was assuned to be involved into the chemical change which might be caused in the photochemical formation of vitamin $D$ by 
irradiation, that substance, consequently, would be readily scen to be sufficient in surprisingly small quantitics. For example, if calculated from my theory that $\Delta$, mono-ozonide ergosterol is vitamin 1 ), the amount of ozone necessary to form the whole close of vitamin D proposed by Kon, Daniels and STFknock (1928) is sufficient in such a surprisingly small quantity as $5 \times 10^{-30} \mathrm{gr}$.

Above all, the question as to whether oxidation plays a role in the activating process by irradiation with ultra-violet rays or not will remain unsolved in the future until the experimental demonstration in an ideal abence of oxygen shall have been achieved.

\section{B. CLRATIVE ACTION OF O\%ONE ON RICKETS WHEN THE RICKETY RATS ARE FED IN AN OZONIZED ALMOSPHERE}

In the present case I attempted a feeding experiment to ascertain whether uzone exerts a curative action on rickets when the rickety rats are fed in an ozonized atmosphere or not, in the same way as ultraviolet rays exert a curative action on rickets when the rickety rats are directly irradiated.

\section{METHOD OF THE FEEMING EXPERIMENT}

Albino rats weighing about $30 \mathrm{gr}$. were put on the McCor.rum rachitogrenic diet $\mathrm{No} .3143$ (whole wheat $33 \%$, Maize $33 \%$ wheat gluten $15 \%$, gelatine $\left.\mathrm{I} 5 \%, \mathrm{NaCl} 1 \%, \mathrm{CaCO}_{3} 3 \%\right)$ and distilled water in a dark room after they had been fed for 25 days on the Srimman basal diet Is (whole dried milk $33.3 \%$, whole wheat $654 \%, \mathrm{NaCl}$ I.3\%) and somc vegetables 2-3 times per week. They bccame rickety on this diet after 35 days and then the curative action of ozone was tested on them, they being fed in an ozonized atmosphere for some days. Each litter of rats was used only throughout one experiment and the grade of rickets disease was compared separately in male and female by means of the histological cxamination (line test) before and after the test period. The food intake of each rat was recorded. And all rats which lost in bocly weights during the test period or ate less than 2 grs. of food per day were discarded.

TECHNIQUE OF I.LNE TEST PROCEIURE

The tibiae were dissected from the tissue after the rats had becn anesthetized with cliloroform and killed, and their longitulinal sections were prepured by means of a freezing microtome, the sections being 
immersed in I \% silver nitrate solution. Light from a carbon arc lamp was focused for 1.5 minutes upon these immersed surfaces and then the histological examination of the bones was carried out.

\section{ANIMAL FEEDING ROOM}

In this experiment in place of a dark animal feeding room was used a large light-tight box $(\mathrm{I} .4 \times 0.7 \times 1.0 \mathrm{~m})$ with a special structure to insulate from light but to permit a ventilation in which the usual animal feeding boxes were placed. The animal feeding room was made dark by drawing a photographer's black cloth curtain over the windows of frosted glass when feeding or other work was attempted.

\section{OYONE-GENERATOR}

Konama's ozone-generator was especially employed in this experiment and placed on the shelf made above in the large animal feeding box which covered fully inclosed the usual animal feeding boxes. Ozone was generated for some ninutes per day in the large animal feeding box by means of the ozone-generator and thus the tested rats were fed in an ozonized atmosphere on the rachitogenic diet.

\section{Curative action of ozone on rickets}

\section{Table I I}

\begin{tabular}{|c|c|c|c|c|c|c|}
\hline \multirow{3}{*}{ Rat No. } & \multirow{3}{*}{$\begin{array}{l}\text { Total length } \\
\text { of time for the } \\
\text { generation of } \\
\text { ozone (min.) }\end{array}$} & \multirow{3}{*}{$\begin{array}{l}\text { Test period } \\
\text { (day) }\end{array}$} & \multirow{3}{*}{$\begin{array}{l}\text { Average amount } \\
\text { of diet eaten } \\
\text { per rat per day } \\
\text { (gr.) }\end{array}$} & \multicolumn{2}{|c|}{ Body weight (gr.) } & \multirow{3}{*}{ Line test } \\
\hline & & & & \multicolumn{2}{|c|}{ test-period } & \\
\hline & & & & before & after & \\
\hline$I(s)$ & I 50.0 & 20 & 7.6 & 74 & 106 & ++ \\
\hline $2(z)$ & 150.0 & 20 & 8.1 & 74 & 118 & ++ \\
\hline $3(3)$ & 150.0 & 20 & 7.7 & 64 & 103 & ++ \\
\hline $4(8)$ & 95.0 & 14 & 7.7 & 58 & 72 & ++ \\
\hline $5(i)$ & 150.0 & 20 & 78 & 64 & 100 & ++ \\
\hline $6(p)$ & 87.5 & 13 & 8.2 & 64 & S6 & + \\
\hline
\end{tabular}

The feeding experiments in table II and table 12 were quite analogous with each other in their experimental method and object but differed respectively as to the mother rat and the experimental date. 
Table I 2

\begin{tabular}{|c|c|c|c|c|c|c|}
\hline \multirow{3}{*}{ Rat No. } & \multirow{3}{*}{$\begin{array}{l}\text { Total length } \\
\text { of time for the } \\
\text { generation of } \\
\text { ozone (min.) }\end{array}$} & \multirow{3}{*}{$\begin{array}{l}\text { Test-period } \\
\text { (day) }\end{array}$} & \multirow{3}{*}{$\begin{array}{c}\text { Average amount } \\
\text { of diel eaten } \\
\text { per rat per day } \\
\text { (gr.) }\end{array}$} & \multicolumn{2}{|c|}{ Body wcightlt (gr.) } & \multirow{3}{*}{ 1.inc test } \\
\hline & & & & test & riod & \\
\hline & & & & before & after & \\
\hline $1(7)$ & 100 & 20 & 6.2 & $6 y$ & 90 & +1 \\
\hline $2(3)$ & 100 & 20 & 6.0 & 75 & 92 & +++ \\
\hline $3(6)$ & 100 & 20 & 5.9 & 8o & 94 & ++ \\
\hline $4(8)$ & 100 & 20 & 5.7 & 70 & 86 & ++ \\
\hline
\end{tabular}

From these cxperimental data it became cvident that ozone exerts certainly some definite curative action on rickets in rats on the rachitogenic diet when the rickety rats are fed in an ozonized atmosphere.

\section{ANTHACIITIC ACTIVATION OF ERGOSTEROL BY MEANS OF TIIE ACTION OF OZONE}

In the present experiment I attempted a feeding experiment to ascertain whether ergosterol becomes an antirachitically active substance after the action of ozone or not, in the same way as ergosterol becomes active after irradiation with ultra-violet rays.

Bhlls, Honerweth and $\mathrm{C}(\mathrm{x}$ ( 1928 ) studied the rate of activation of ergosterol during irradiation with ultra-violet rays. Jn their expcriment the maximum potency was reached in 22.5 minutes, at which time the ergosterol was 250,000 times as potent as average cod liver oil. From this time further irradiation caused a falling off in potency, the product becoming inactive in about 3 hours. It has not yet been explained clearly why the initially formed activated ergosterol changes again to an antirachitically inactive substance through over-irradiation, but the presence of this phenomenon is being clearly recognized by many investigators. Taking this phenomenon into consideration, I attempted herc to demonstrate experimentally my suggestion that ergosterol wiil bccome an antirachitically active substance after the appropriate action of ozone. For this purpose, Shimazu's primitive ozone-generator with one-tube was especially employed in this experiment from which ozonc was gencrated about the same quantity as in the case of irradiation with an Acue mercury vapour quartz lamp. 
METHOI) OF PREPARING LRGOSTEROL,

Frgosterol was isolated from beer-ycast by means of the Hriduscuki and LiNoner's modification (1929) of the Windaus and Grosskopr's methol (1922) and was recrystallized two times from cthyl-alcohol, once from acetone. The melting point of the ergosterol was $154^{\circ} \mathrm{C}$ (uncorrected). The ergosterol in itself was antirachitically inactive on a feeding experiment.

OZONE-GENERATOK AND CONDITIONS FOR THE ACTION OF OZONE

The Simazu's ozone-generator with one-tube (see Fig. 3.) was especially employed in this experiment for the above-mentioned reason. An induction coil having $3.5 \mathrm{~cm}$. length of spark and dry cells (43 volts) which were arranged serially with throe dry cells, were attached to the ozone-generator. Each o\%one-gencrator and small cylindrical bottle served with sample was deeply placed separately in a large porcelain buttle. Ozone was generated by passing in at 20-25 1/1 velocity oxygen gas which had been purificel through conc. sulphuric acid and over soda-lime.

O\%ONI\%ED ERGOSIEROLS ANI METHODS OF PRHAPARING THES:

Ergosterol ( $20 \mathrm{mg}$.) was dissolved in $10 \mathrm{cc}$. of olive oil and then czonized for a definte fime under the above-describucl conditions. One drop of this olive oil solution corresponels to $0.1 \mathrm{mg}$ of ergosterol. The olive oil solution ozonized under the above-described conditions was, if necessary, clituted with olive oil so that onc diop of the olive oil solution corresponds to $0.05 \mathrm{mgr}$. or to $0.015 \mathrm{mg}$. of crgosterol.

Now under the above-described conditions, ergosterol (20 mg) in clive oil ( $10 \mathrm{cc}$.) ozonized for 0.5 minutes was designated as " $0 \%$ Erg. I" and those for 3, 6 minutes respectively as "Oz. Ligg. If" and "O\% Erg III." Oz. Erg. II was diluted with olive vil so that one drop of the olive oil solution corresponds to $0.05 \mathrm{mg}$. or to $0.015 \mathrm{mg}$. of ergosterol. The former was clesignated as "Oz. lire. IV" and the latter as "Oz. Frgr. V."

\section{METHODS FOR IELIING IEXERIMENT}

The methols of this fecling experiment were nearly similat to those of the preceling fecding experiment. Tle samples to be tested were nut incorporated in the diet, but one drop of the olive oil solutions was administered daily per rat by means of a glass-spatula. 
Antirachitic potency of ozonized ergosterol

Table $\quad$ 3

\begin{tabular}{|c|c|c|c|c|c|c|}
\hline \multirow{3}{*}{ Rat No. } & \multicolumn{2}{|c|}{ Days of the feeding } & \multirow{2}{*}{\multicolumn{2}{|c|}{$\frac{\text { Body weight (sr.) }}{\text { and period }}$}} & \multirow{3}{*}{$\begin{array}{l}\text { No. of sampies } \\
\text { to be tested }\end{array}$} & \multirow{3}{*}{ I.ine test } \\
\hline & \multirow{2}{*}{$\begin{array}{c}\text { Ist period. } \\
\text { (on rickets. } \\
\text { producing dict) }\end{array}$} & \multirow{2}{*}{$\begin{array}{l}\text { and period } \\
\text { (on test diel) }\end{array}$} & & & & \\
\hline & & & before & after & & \\
\hline $\mathrm{I}(b)$ & 21 & 14 & 64 & 92 & Oz. lirg. I & -- \\
\hline $2(E)$ & 21 & 14 & 42 & 57 & Oz. Erg. I & - \\
\hline $3(\hat{o})$ & $2 \mathrm{I}$ & 14 & 51 & 60 & Oz. Frg. II & +++ \\
\hline $4(8)$ & 21 & 14 & 43 & 54 & Oz. Lrg. II & $+t+$ \\
\hline $5(9)$ & 21 & I 2 & 40 & 54 & Oz. Erg. II & $++t$ \\
\hline $6(0)$ & 21 & 14 & 45 & 6 & (). Ergr. II & ++ \\
\hline $7(\hat{6})$ & 21 & 14 & 57 & 82 & Oz. Erg. II & \pm \\
\hline $8(3)$ & 21 & $I_{4}$ & 58 & 87 & Oz. Erg. III & \pm \\
\hline $9(\hat{o})$ & 25 & 18 & $4 \mathrm{I}$ & 57 & Oz. Frg. II & $++t$ \\
\hline Io $(\pi)$ & 25 & 18 & 46 & 66 & Oz. Erg. II & $+t$ \\
\hline$I 1(\hat{O})$ & 25 & 18 & 42 & 49 & Oz. IVIg. IV & +++ \\
\hline $12(3)$ & 25 & 19 & 32 & 40 & Oz. Erg. IV & +++ \\
\hline $\mathrm{I} 3(\hat{b})$ & 25 & 18 & 35 & 45 & $O \%$ lirg. $V$ & + \\
\hline
\end{tabular}

In line test,,+++ and +++ signs express respectively moderate healing, advanced healing and complete healing, \pm sign prevention and - sign expresses as deterioration.

From the results of the fecding cxperiments as recorded above it becomes cxperimentally certain that ergosterol becomes an antiraclitically active substance after the action of ozone. And it becamc evident also that the rate of activation of ergosterol increased after the action of ozone and then reached a maximum potency and from this time further action caused a falling off in potency, the product becoming completely inactive (one can readily see the presence of such a phenomenon also in the case of the activation of ergosterol through the irradiation with ultra-violet rays). And it further became clear that under my experimental conditions, a daily dose $0.1 \mathrm{mg}$. and $0.05 \mathrm{mg}$. of the ergosterol ozonized for 3 minutes was sufficient to heal rickets 
completely and a daily dose $0.015 \mathrm{mg}$. was somewhat efficaious, while ergosterol o\%onized for 0.5 minutes was no cfficacious and ergosterol ozonized for 6 minutes prevented even in a daily dose o.I $\mathrm{mg}$. in both cases.

It may be summarized from experiment IV that (I) osone excrted certainly some definite curative action on rickcts in rats on the rachitogenic diet when the rickety rats were fed in an osonized atmosphere (2) ergosterol was activated antiraclitically by the appropriate action of ozone.

\section{DISCUSSION}

One cannot have now any accurate knowledge on the chemical nature of vitamin I) except the fact that the antiraclically inactive ergosterol is photochemically converted into vitamin $D$ after irradiation with a mercury vapour quart $\%$ lamp. Many investigators almost attempt to make clear the chemical nature of vitarnin I) by means of the isolation of a pure active fraction from irracliated ergosterol, but they do not succeed in it. On the other hand I attempt here to elucidate the chemical nature of vitamin D by making evident the significance of the action of ultra-violet rays on the photochemical conversion of ergosterol into vitamin $\mathrm{D}$.

From my experimental results, it has now become evident that vitamin $\mathrm{D}$ is formed from ergosterol after the appropriate action of ozone. Then it should be considered what chemical changes take place to form vitamin $D$ from ergosterol by the action of ozonc.

Those which are formed by the chemical action of ozone are in general the ozonide and in special case the ozonide-peroxide and the polymer. Let us now herc cxamine closely by means of the criteria of my experimental results which of these products of ergosterol produced by the action of ozone is in connection with vitamin $D$. The ozonidepcroxide will be readily seen to be in no connection with vitanin $D$ from the fact that this product is produced when strongly ozonized, The polymer may be produced by such a weak action of ozone as was employed in my experiment, but it is also being generally admitted that the polymer is produced in additition to the ozonide when moderate strongly ozonized. Therefore, the polymer will also be readily seen to have no connection with vitamin $\mathrm{D}$ from the fact that vitamin $\mathrm{D}$ is formed from ergosterol by the appropriate action of ozone but the 
initially formed active substance becomes again an inactive product by the excessive action of ozonc. Consequently the ozonicle of ergosterol must be vitamin $D$.

But on the other hand, it was scen in my experiment as in Sumis paper (1930) that ergosterol ozonide obtained by passing ozone completely or strongly upon ergosterol was antitachitically inactive, and in my experiment it also became clear that ergosterol became antirachitically active after the appropriate action of ozone. Thercfore, it cannot be immediately decided that ergosterol ozonide is vitamin $\mathrm{D}$.

Hereupon such a hypothesis was assumed as follows; namely, cvery three double bonds in ergosterol differs, respectively in the power to conibine with ozone according to its position in the structure of ergosterol. From this hypothesis, the most common ozonide formative double bond among them was expressed with $\triangle_{1}$, in orler $\triangle_{I}$ and $\triangle_{\text {II1 }}$. Frgostcrol having one ozonide only at $\Delta_{I}$ and none at $\triangle_{I I}, \triangle_{I I I}$ is now designated as " $\triangle_{1}$ mono-ozonide ergostetol" and ergostcrol having two ozonicles at $\triangle_{I}, \Delta_{I I}$ and not at $\triangle_{\text {III }}$ is designated as " $\triangle_{1}$, n di-ozonide ergosterol" and ergosterol having three ozonides at $\triangle_{I}, \triangle_{I I}$ and $\triangle_{I . I}$ is designated as " $\triangle_{I}$, II , II tri-ozonide ergosterol."

We must next examine closely which of these three ozonides of ergosterol corresponds to vitamin $\mathrm{D}$. What one means in general by crgosterol ozonide is $\Delta_{\mathrm{I}}$, II, in tri-ozonide ergosterol and it has been made clear above that this substance is antirachitically inactive. Therefore, vitamin $D$ must be $\Delta_{I}$ mono-ozonicle ergosterol or $\Delta_{1}$, in diozonide ergosterol.

On consideration of a quantity of ozone necessary to the activation of ergosterol, a concentration of ozone to be used in the reaction and of a shape of the activation curve of ergosterol by irradiation with ultra-violet rays or by the action of ozone, it appears to be more reasonable that vitamin $D$ is $\Delta_{\mathbf{r}}$ mono-ozonide ergosterol rather than $\Delta$ : , II di-o\%onide ergosterol. The rate of the activation of ergosterol in point of fact increased with a rapid curve and reached to the maximum potency and then decreased with a slow curve. If $\triangle_{r}$, in di-ozonide crgosterol was assumed to be vitamin $\mathrm{D}$, the rate of the activation should increase with a slow curve and reach to the maximum potency and then decrease with a rapid curve. If $\Delta_{I}$ mono-ozonide ergosterol was assumed to be vitamin $\mathrm{I}$, the presence of maximum point in the activation curve, and also of the fact that initially formed active sub- 
stance becomes again inactive, would be readily understood if this phenomenon is explained as follows; namely, the initially formed active $\triangle_{I}$ mono-ozonide ergosterol alters gradually to the inactive $\Delta_{I}$, II di.ozonide crgosterol and $\Delta_{I}$, It, III tri-ozonide ergosterol through ovir-irradiation or excessive action of ozone. Bourdollon, Fischmani, Jexkins and Websiek (1929) reported recently that on stirring the liquic during radiation by a steam of nitrogen, the three substances "A," "B," "C" were isolated from the irradiated crgosterol among which "A" substance was very strongly antirachitically active and "B," "C" substances inactive. They suggested that "A " substance would be vitamin $\mathrm{D}$ and explained the fact that the initially formed active substance becomes gradually an antirachitically inactive substance after over-irradiation with ultra-violet rays as follows; nanely, "A " active substance alters gradually to the "B," "C" inactive substances through over-irradiation. If " $A$ " substance was assumed to be $\Delta_{1}$ mono-ozonide crgosterol and " $\mathrm{B}$," "C" substances respectively to be $\triangle_{1}$, If di-ozonide ergosterol and $\Delta_{1}$, II, II tri-o\%onide ergosterol, their experimental results would be readily seen to be in hamony with my theory that $\Delta_{I}$ mono-ozonide ergosterol is vitamin $D$.

It will require a determination of the chemical structure of ergosterol, to demonstrate experimentally my theory on the chemical nature of vitamin $\mathrm{D}$, but I believe from the experimental resulis obtained above that $\Delta r$ mono-ozonide ergosterol will possibly prove to be vitamin 1 ).

But if my theory is roughly expressed, it is concluded such that the imperfectly ozonized ergosterol is vitamin $\mathrm{D}$.

Vitamin A was formerly supposed to be probably lipochrome pigments or substances in their intimate relation but on investigation it was experimentally demonstrated that these pigments have none of the properties of vitamin A. On the other hand, it became recently evident that what was regarded as vitamin $A$ had been in reality the mixture of vitamin $A$ and vitamin $D$. Thereafter, having examined again the behaviours of these lipochrome pigments in the presence of vitamin $D$, Euler, Euler and Hellström (1928) demonstrated the fact that carotin has the properties of vitamin $A$ in the presence of vitamin $D$ (the irradiated ergosterol was used). Thereafter, MoOre (I929), Collison, Hume, Smedley-Mcleax and Smiti (1929), and Kawakami and Kin 
(1929) confirmed this fact experimentaliy. And recently KAWAKAMn and Kin (1930) demonstrated that vitamin $A$ in cod liver oil is not carotin and proposed that there are possibly several kinds of vitanin $A$. Certainly, at the present time vitamin $A$ can be considered to be a mixturc of vitamin $\mathrm{D}+$ carotin or $\mathrm{x}$ substance.

On the other hand, it was formerly made evident by ZiiBA (1922) that vitamin A loses its physiological action through the action of ozone. And the cause of this phenomenon still remains uncxplained. But if it was seen from my theory that $\triangle_{I}$ mono-ozonick ergostcrol is vitamin $\mathrm{D}$, this phenomenon could be readily explained as follows: namely, becausc vitamin $\mathrm{D})\left(\Delta_{1}\right.$ mono-ozonicie ergosterol) loses its physiological action by altering to the inactive $\Delta_{1}$, и di-ozonide ersosterol or $\Delta_{1}$, II, an tri-ozonide ersosterol through the action of ozone, vitania $A$ (vitamin 1$)+$ carotin or $x$ snbstance) results to be carotin or $\mathrm{x}$ substance and to lose the physiological action of vitamin $A$ as if lipoclirom pigments have no physiological action of vitanin $\Lambda$ in the absence of vitamin $D$.

\section{SUMMARY}

1. Vegetable cils after irradiation with ultra-violet rays were lexs readily hydrolysed by the castor-bean lipase than were the original and the greater the iodine value the greater was the infuence of irradiation, and the decrease in the enzymic hydrolysis-velocity of oil is directly proportional to the length of tine of irridiation.

There existed a certain corretation between the iodine value of vegetable oil and its enzymic hydrolysis-velocity; namely, the greater the iodine value the less was the velocity and from this fact the nutritive value of fit and oil was assumed to be insersely proportional to its iuline value. The viscosity of vegetable ail ran parallel with its enzymic hydrolysis-velocity; namely, the greater the viscosity the greater was the velocity.

2. The action of ultra-violet rays which decreise the enyymic hydrolysis-velocity of vegetable oils, increase the acjd value and the viscosity, and decrease the iodine value of the oils, was nothing but the action of ozone, and the ultra-violet rays corresponded to an ozonegenerator when seen from the viewpoint of enzymology.

3 The action of ozone upon cholesterol and oil was closely 
analogous to that of ultra-violet rays as regards photoactivity, colour reactions, etc.

4. Ozone cxerted some definite curative action on rickets in rats on the rachitogenic diet when the rickety rats were fed in an ozonized atmosphere.

5. Esgosterol was activated antirachitically after the appropriate action of ozone.

6. The rate of activation of ergosterol after the action of ozone increased gradually and then a maximum point of potency was reached but thercafter the further action caused a falling off in potency, the product becoming inactive at last.

7. Under my cxperimental conditions, a daily dose o. $1 \mathrm{mg}$. and $0.05 \mathrm{mg}$. of ergosterol ozonized for 3 minutes was sufficient to heal rickets completely and a daily dose oor $; \mathrm{mg}$. was somewhat efficacious. Frgosterol ozonized for 0.5 minutes was not efficacious and crgosterol ozonized for 6 minutes prevented even in a daily dose o. $1 \mathrm{mg}$. in both cases.

8. It was suggested from my cxperimental results that $\Delta_{1}$ monoozonidc ergosterol will possibly be vitamin D. And also it was roughly concluded such that the imperfectly ozonized ergosterol is vitamin D.

\section{REIERENCES}

BH.ts, Honfyw:Le and (ix; J. Birl. Chem., So, 557 (1920).

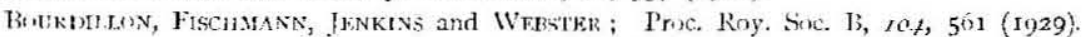

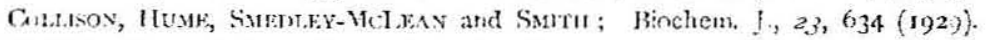

Cowaks 11.; Binchem. I, 23, 1221 (1928).

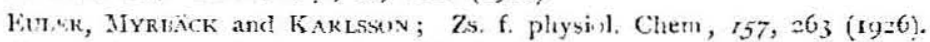

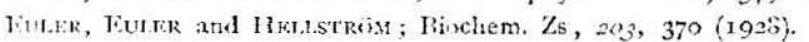

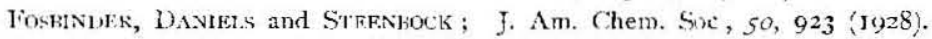

J[Амахо, S.; J. Agr. Chem. Snc., (Japan;, $r, 880$ (1925).

Histuschks and lindnak; 7s. f. physiil. Chem, 787,15 (r929).

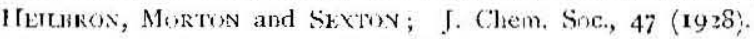

IJ,sis and Weinstoxk; J. Biol. Chem., $0_{3}, 297$ (1925).

Hoss and WINIAUS; Proc. Suc. Wip. Miol. Mcd., 2f, 172 (1926).

Ilumbcilisky; Deul. Med. Wich., 45, 712 (1919).

Kawakami and Kix; Frox. Imp. Acad. Tikyo., 5, 213 (1929).

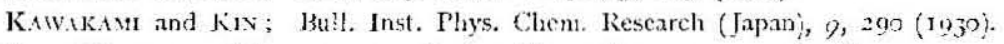

Kinn, Dinils and Starniock; J. Am. Chem. Snc., 5o, 2573 (1928).

Ix:cAs, N. S.; IBinchem. J., 20, 23 (1926).

Matsurama, M. and Yostuda, M.; J. Agr. Chen. Snc. (Japan), 3, 633 (1927).

MCCollim and on-sworkers; J. Bint. Chem., 5o, 5; 5t, 41 (1922). 
Mouke and Wuldurte; Birchem, J., 2s, 585 (1927).

Moонт, 1.; Rinchem. I., 2.3, 803 (1929).

O7.AkI, J. ; J. Agr. Chem. Sinc. (Japar), 3, 983 (r927).

RusENHFIM and WFBsTFR; Bischem. J., 20, 537 (1926).

Rustanifim and Wfustik; Binchem. J., 21, 127, 38) (1927).

Rosknthim and Whistike; Jinchem. J., 22, 762 (I928).

Scumit7, Ziegare and Morse; J. T3iol. Chem., 7.7, 209 (1927).

Srxpun, W. A.; Biochem. J., 22, 1133 (1928).

Surak, M. J, P'rnc. Snc. Fixp. Biol. Med., 2.3, 546 (1926).

SHFAR and KRAMrK; J. Jini. Chem., $71,213,221$ (I926).

Siskevbook and Br.Ack; J. Bis). Chem., $6 r, 405$ (1924).

Strmonick and $c$-wirkers; I. Itisi. Chem, 6.7, 263 (1925).

Simgmann, A.; Krlloid.7.s., 75,165 (1928).

STrniteski, J.; Binchem. Zs, $1 S_{7}, 383$ (1827).

Sinal, M.; J. Agr. Chem. Six. (Japanj. 6, 682 (1930).

Taknmira, J..; J. Agr. Chem, Soc. (Japan), 2, I (ryz6).

Ufove, S.; J. Soc. Chem. Ind. (Japan). ,30, 37\% (t927).

Volimf.k, II.; Birchem. Zs., 172,$467 ; 17.7,389,467 ; 17.7,143 ; 176,84$ (1926).

Votimt.k and Strerkijski; Binchem. Zs., $77^{h}, 84$ (1926).

Winuaus and Circsskopr ; Zs. f. physinl. Chem., 12/, 8 (1922).

WivJ)ACs and lluss; Nachr. Ges. Wiss. Göttingren, Math-physik. Klasse 185 (1926).

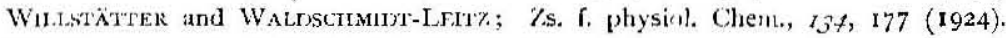

Y(н)к, I.; J. Binl. Chem., 70, 297 (1926).

Z.ILBA; Jinchem. J., 16,42 (1922). 
EXIIANATION OF PIATE I

Fig. I A: Original olive oil

B: Ozonized olive oil.

Fig. 2 A: Original cholesterol.

B : Irradiated cholesterol.

C : Oronized cholesterol I.

D) : Oronized cholesterol II.

Fig. 3 Shimazu's ozone-generator. 
Fig. I.

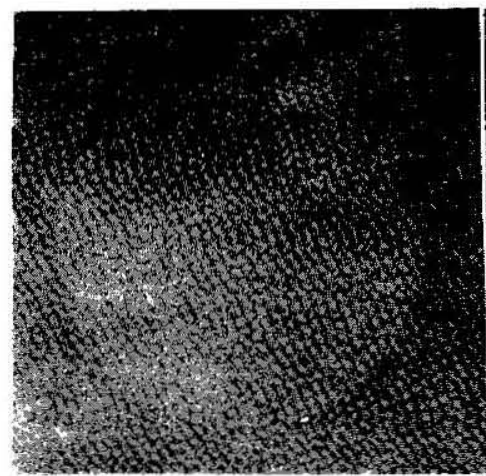

A

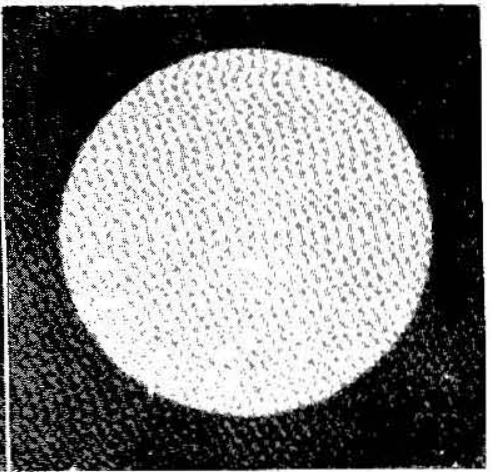

B

Fig. 3 .

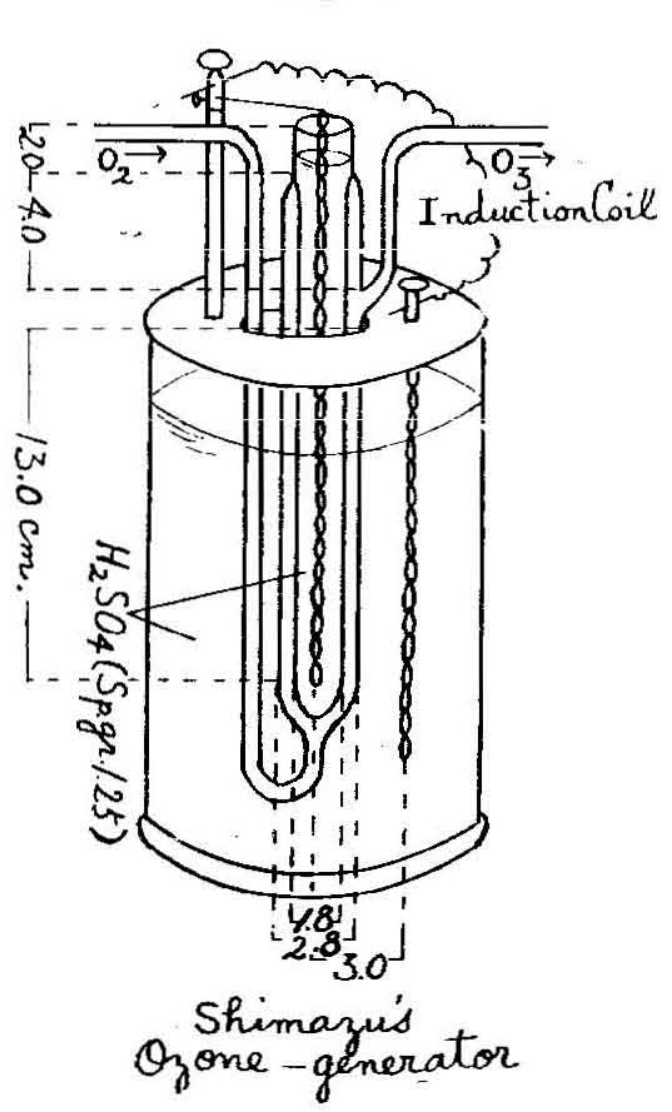

Fig. 2.
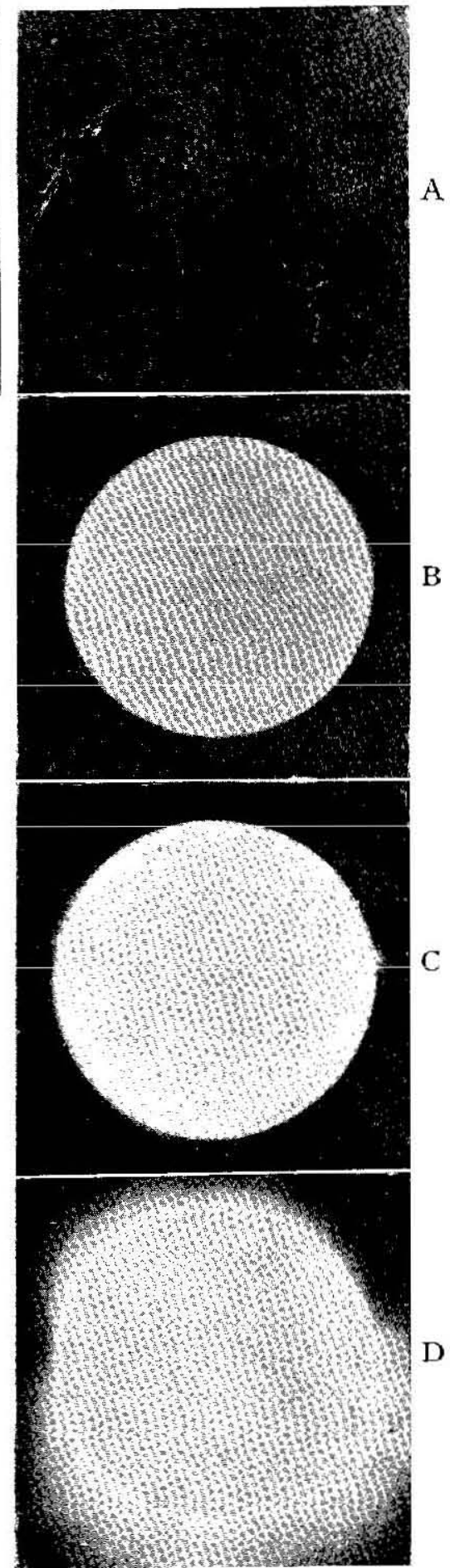